\title{
Kesiapan Lansia dan Caregivers di Jabodetabek Dalam Melakukan Praktek Pencegahan Penularan Covid-19 Pada Masa Pandemi
}

\author{
Tri Suratmi ${ }^{1,4}$ Dinni Agustin $^{2,4}$, Nur Apriyan ${ }^{3}$, Tri Budi W.Rahardjo ${ }^{1,4}$ \\ ${ }^{1}$ Program Studi Kesehatan Masyarakat, Fakultas Pascasarjana Universitas Respati Indonesia \\ ${ }^{2}$ Fakultas Manajemen dan Administrasi Bisnis Universitas Respati Indonesia \\ ${ }^{3}$ Fakultas Ilmu Kesehatan Universitas Respati Indonesia \\ ${ }^{4}$ Centre for Family and Ageing Studies (CeFAS) Universias Respati Indonesia \\ dinniagustin@urindo.ac.id
}

\begin{abstract}
Abstrak
Wabah penyakit yang disebabkan Virus Corona terjadi mulai akhir tahun 2019, berawal dari Wuhan China, yang kemudian dikenal sebagai COVID-19. Sampai dengan bulan Mei 2020, COVID-19 telah melanda semua negara, tak terkecuali Indonesia. Upaya meminimalisir Lansia dari paparan COVID-19, serta dampaknya perlu dilakukan dengan tepat. Oleh karena itu dilakukan survey dengan tujuan mengukur tingkat pengetahuan, sikap, dan praktik terkait COVID-19 di kalangan Lanjut usia yang umumnya lebih rentan terhadap komplikasi infeksi karena usia dan kondisi komorbiditas, serta peran pendamping/Caregivers (formal dan non-formal) yang diharapkan dalam memberikan pelayanan pada masa pandemi COVID-19. Pendekatan secara kuantitatif dilakukan di 5 (lima) lokasi dengan tingkat kasus tertinggi di Indonesia yakni di wilayah Jabodetabek, menggunakan instrumen melalui google form survey. Hasil: sejumlah 694 responden berpartisipasi pada survey ini, terdiri dari 507 orang lansia perempuan dan 187 lansia laki-laki, dengan pendidikan (49\%) berpendidikan rendah dan (51\%) berpendidikan tinggi. Pada praktik pencegahan COVID-19 responden yang telah sesuai menerapkan protokol kesehatan cukup besar; 592 responden (85.3\%). Pengetahuan responden dalam melakukan pencegahan COVID-19 terbilang sangat tinggi; 417 orang dari total responden (60,1\%). Sikap responden terhadap pencegahan COVID-19 juga cukup baik; 479 responden (69\%) dari total responden. Sedangkan peran Caregivers dalam melakukan pencegahan COVID-19 rata-rata responden menyatakan bahwa Caregivers sangat berperan aktif dalam melakukan pencegahan COVID-19; 614 responden (88.5\%). Kesimpulan: Pengetahuan tentang COVID-19 pada lansia dan Caregivers cukup baik, Sikap sebagian besar positif dan Praktik sebagian besar juga sudah sesuai dengan protokol kesehatan. Tidak terdapat hubungan antara Knowledge Attitude Practice (KAP) dengan praktik pencegahan COVID-19.
\end{abstract}

Kata kunci: COVID-19, Knowledge Attitude Practice (KAP), lansia, peran Caregivers

\begin{abstract}
The disease outbreak caused by the Corona Virus began at the end of 2019, starting in Wuhan China, which became known as COVID-19. As of May 2020, COVID-19 has hit all countries, including Indonesia. Efforts to minimize the elderly from exposure to COVID-19 and its impacts need to be done appropriately. Therefore a survey was done with the goal to measuring the level of knowledge, attitudes and practices related to COVID-19 among elderly people who are generally more susceptible to infectious complications due to their comorbid conditions, and the expected role of the Caregivers (formal and informal) in providing care during COVID-19 pandemic. A quantitative approach was carried out in 5 (five) locations with the highest case rates in Indonesia, namely Jakarta, Bogor, Depok, Tangerang and Bekasi (Jabodetabek), using an instrument shared through a http://ejournal.urindo.ac.id/index.php/jukmas
\end{abstract}

Article History :

Submitted 06 Februari 2021, Accepted 28 Oktober 2021, Published 31 Oktober 2021 
google form survey. Results: a number of 694 respondents participated in this survey, consisting of 507 elderly women and 187 elderly male, with $49 \%$ having low education and $51 \%$ having high education. In the practice of preventing COVID-19, respondents who have been appropriate to implement health protocols are quite large; 592 respondents (85.3\%). Respondents' knowledge of preventing COVID-19 is very high; 417 people from the total respondents (60.1\%). The attitude of respondents towards preventing COVID-19 is also quite good; 479 respondents (69\%) of the total respondents. Meanwhile, the role of Caregivers in preventing COVID-19, on average, respondents stated that Caregivers played an active role in preventing COVID-19; 614 respondents (88.5\%). Conclusion: Knowledge of COVID-19 among elderly and Caregivers is quite good. Attitudes are mostly positive and practice is mostly in accordance with health protocols. There is no relationship between Knowledge Attitude Practice (KAP) with COVID-19 prevention practice.

Keyword: COVID-19, Knowledge Attitude Practice (KAP), older persons, Caregivers' role

\section{PENDAHULUAN}

World Health Organization (WHO), pada Januari 2020, mengeluarkan pernyataan mengenai Corona Virus Deseases-19 (COVID19) sebagai keadaan darurat bagi masalah Kesehatan Masyarakat yang meresahkan dan melanda seluruh dunia. Untuk menangani masalah pandemi COVID-19 ini diperlukan kesiapan pada kondisi tanggap darurat yang bersifat kritis antara lain dengan melengkapi tenaga kesehatan serta manajemen pelayanan kesehatan dengan informasi, prosedur, dan alat yang penting agar mereka dapat aman dan efektif dalam melaksanakan pekerjaannya(1).

Salah satu kelompok yang rentan terhadap infeksi COVID-19 adalah lanjut usia (lansia) karena memiliki morbiditas dan mortalitas yang tinggi serta mereka merupakan kelompok usia yang sangat memerlukan akses terhadap layanan kesehatan, karena sebagian besar lansia memiliki penyakit kronik/degeneratif. Oleh karena itu upaya pencegahan penularan COVID-19 dapat dilakukan melalui upaya promotif dan preventif menjadi prioritas, baik di tingkat komunitas maupun di fasilitas kesehatan(2).

Hal senada disampaikan oleh Center for Desease Control (CDC) USA, bahwa lansia adalah kelompok yang rentan untuk terinfeksi virus Corona SARS-CoV-2 penyebab COVID19(3). Akan tetapi, justru kelompok lansia ini yang dapat dikatakan sulit untuk mematuhi imbauan pemerintah untuk mencegah agar tidak terinfeksi, misalnya dengan cara selalu menjaga jarak. Dalam beberapa kasus, Iansia cenderung keras kepala dan tidak acuh terhadap imbauan-imbaun pencegahan seperti itu. Pada saat ada himbauan untuk selalu memakai masker dan mengusahakan untuk tetap tinggal dirumah, akan tetapi mereka meresponsnya bahwa pengap bila memakai masker $(3,21)$

Oleh karena itu harus ada orang yang mendampingi lansia untuk menjalani masa pandemi dengan tenang. Orang yang mendampingi lansia melewati masa-masa sulit ini harus orang yang tepat. Berkomunikasi dengan lansia yang enggan 
untuk melaksanakan anjuran dari pemerintah, sebaiknya dimulai dengan sabar dan tetap memiliki respek. Mereka akan tetap menganggap anaknya adalah anak kecil, merekalah yang benar dan tahu semua hal.

Seandainya terjadi kondisi ini, maka sebaiknya menujuk anggota keluarga lain yang lebih dianggap berwibawa atau dipercaya agar dapat mengirimkan amanat yang dapat diketahui oleh lansia sekaligus dapat memberikan pendampingan. Seseorang yang mendampingi lansia untuk dapat membantu memenuhi kebutuhan hariannya kita kenal sebagai Caregivers/pendamping lansia, baik yang formal (berbayar) maupun yang nonformal (tidak berbayar, baik itu seseorang yang masih memiliki ikatan keluarga, atau sukarelawan)(4,16).

Caregivers, dalam hal ini pendamping lansia [formal maupun non-formal] sangat penting perannya dalam memberikan layanan sehari-hari, terlebih mereka harus tanggap terhadap penyebaran COVID-19 yang terjadi saat ini serta sekaligus menjadi tulang punggung layanan bagi lansia dalam menanggulangi agar lansia tidak terdampak. Dalam upayanya melindungi masyarakat lebih luas dalam hal lansia, mengetahui pengetahuan, sikap dan praktek terkait virus COVID-19 pada lansia sangat penting untuk melindungi diri mereka sendiri, kemudian peran apa yang lansia harapkan dari seorang Caregivers/pendamping baik itu pendamping formal maupun non-formal dalam pelayanan pendampingan di masa pandemi COVID19(4,16).

Severe Acute Respiratory Syndrome Coronavirus 2 (SARS-CoV-2) adalah virus yang menyerang sistem pernapasan. Penyakit infeksi ini dikenal dengan COVID-19. Corona virus adalah kumpulan virus yang bisa menginfeksi sistem pernapasan. Pada banyak kasus, virus ini hanya menyebabkan infeksi pernapasan ringan, seperti flu. Namun, virus ini juga bisa menyebabkan infeksi pernapasan berat, seperti infeksi paru-paru (pneumonia), dan dapat menyerang kepada siapa saja, baik bayi, anak-anak, orang dewasa, lansia, ibu hamil, maupun ibu menyusui $(5,6)$.

Sehubungan dengan penjelasan tersebut, maka dilaksanakan penelitian ini yang bertujuan untuk mempelajari dan menjelaskan tingkat pengetahuan, sikap dan praktik Lansia di Jabodetabek terkait pencegahan virus COVID-19, serta peran Caregivers dalam melaksanakan pendampingan kepada Lansia.

\section{METODE PENELITIAN}

Penelitian ini merupakan survey dengan pendekatan kuantitatif dan rancangan cross-sectional dilakukan pada bulan MaretAgustus 2020, untuk mengumpulkan dan mengotomatisasi analisis pengetahuan, sikap, praktik. Target responden adalah 500 Caregivers dan lansia di 5 kota di Indonesia yang dianggap mewakili kota-kota besar dengan populasi lansia yang tinggi. 
Lokasi penelitian ini dilaksanakan di 5 kota Jakakarta, Bogor, Depok, Tangerang dan Bekasi (JABODETABEK) dengan alasan sasaran reponden lansia dengan prevalensi terbesar berada di Jabodetabek. Waktu penelitian dilakukan pada bulan Maret - Agustus 2020.

Populasi dalam penelitian ini adalah lansia dan Caregivers yang bermukim di Jabodetabek saat terjadi pandemi COVID-19. Sedangkan sampel yang dijadikan responden dalam penelitian ini adalah lansia yang mampu mengakses informasi melalui gadget/online survey(19). Pengambilan sampel dilakukan dengan cara acidental (acidental sampling).

Data penelitian dikumpulkan menggunakan instrumen berupa kuesioner tertutup yang dikonstruksi oleh peneliti berdasarkan indikator dari variabel yang diteliti. Uji validitas dan reliabilitas instrumen dilaksanakan pada 30 sampel uji coba. Data dikumpulkan secara on-line melalui google form. Analisis data akan dilakukan secara univariat dan bivariat.

\section{HASIL DAN PEMBAHASAN}

Hasil penelitian disarikan dalam beberapa tabel berikut dibawah ini. Dalam tabel 1 terkait karakteristik responden yang berpartisipasi dalam mengisi survey ini terlihat sejumlah 694 orang responden dari target awal 500 orang responden. Responden terdiri dari 507 orang Lansia perempuan dan 187 Lansia laki-laki, dengan pendidikan (49\%) berpendidikan rendah dan (51\%) berpendidikan tinggi. Status pernikahan mereka adalah sebanyak 447 menikah, dan 2 orang tidak menikah, 245 orang berstatus janda dan duda. Untuk status pekerjaan responden yang terbesar adalah berstatus sebagai pensiunan (13.3\%), sedangkan yang tidak memiliki pekerjaan lagi adalah sebesar (55.8\%).

Menurut WHO(7,17), Lansia adalah seseorang yang telah berusia 60 tahun keatas. Lanjut usia termasuk pada kelompok umur yang memasuki fase akhir kehidupannya. Pada mereka yang dikategorikan lansia ini akan mengalami suatu proses yang disebut Aging Process atau proses menua. Perubahan tersebut tentunya akan mempengaruhi pada mundurnya kesehatan fisik dan psikis yang pada akhirnya tentu akan berpengaruh pada kondisi ekonomi dan sosial lansia. Perubahan ini pada umumnya akan berpengaruh pada kegiatan hidup sehari-hari/activity of daily living (8). Oleh karena itu peran pendampingan oleh Caregivers baik informal dan non-formal sangat signifikant $(9,16)$ 
Jurnal Untuk Masyarakat Sehat (JUKMAS)

Tabel 1. Karakteristik Demografi Responden

\begin{tabular}{lll}
\hline Karakteristik & Keterangan & Jumlah Responden \\
\hline Jenis kelamin & Laki-laki & $194(28 \%)$ \\
\cline { 2 - 3 } Kelompok umur & $29-49$ tahun/pra-lansia & $187(26,9 \%)$ \\
\cline { 2 - 3 } Status perkawinan & Menikahun/lansia & $507(73.1 \%))$ \\
\cline { 2 - 3 } & Tidak Menikah & $447(64.4)$ \\
\cline { 2 - 3 } Pendidikan & Janda/duda & $2(0.3)$ \\
\cline { 2 - 3 } & SD & $245(35.3)$ \\
\cline { 2 - 3 } & SMA & $228(32.9)$ \\
\cline { 2 - 3 } & Akademi/Universitas & $259(37.3)$ \\
\hline Pekerjaan & PNS/ASN & $95(13.7)$ \\
\cline { 2 - 3 } & Pensiunan & $20(2.9)$ \\
\cline { 2 - 3 } & Wiraswasta & $53(7.6)$ \\
\cline { 2 - 3 } & Tidak Bekerja & $387(55.8)$ \\
\cline { 2 - 3 } & Lainnya & $28(13.4)$ \\
\cline { 2 - 3 } & Ibu Rumah Tangga & \\
\hline
\end{tabular}

Selanjutnya disajikan hasil mengenai pengetahuan, sikap dan praktek dari Lansia mengenai COVID-19. Pada tabel 2 dibawah ini dapat terlihat bahwa responden yang memiliki pengetahuan tinggi tentang COVID19 ada sebanyak 417 orang dengan presentase $(60,1 \%)$, sedangkan responden yang memiliki pengetahuan rendah tentang
COVID-19 ada sebanyak 277 orang dengan presentase $(29,9 \%)$. Temuan ini sejalan dengan penelitian sebelumnya di Mesir dan China, yang melaporkan bahwa sebagian besar responden percaya bahwa COVID-19 lebih berbahaya bagi orang tua dan mereka yang menderita penyakit kronis $(22,25)$

Tabel 2. Pengetahuan dalam Pencegahan COVID-19

\begin{tabular}{ccc}
\hline Pengetahuan & Jumlah & Persentase \\
\hline Tinggi & 417 & $60,1 \%$ \\
Rendah & 277 & $39,9 \%$ \\
& & \\
\hline
\end{tabular}

Hasil kajian Bloom mengenai Pengetahuan, Sikap, dan Praktek terdiri dari tiga bagian utama, yaitu ranah 1)kognisi, 2)afeksi, dan 3)psikomotorik. Perkembangan selanjutnya, pendapat Bloom ini kemudian diganti dalam hal ukuran hasil untuk 
Pengetahuan, Sikap, dan Praktik(10,25).

Dalam hal ini Pengetahuan(11,22) adalah suatu akibat yang timbul karena rasa ingin tahu yang terjadi pada saat pencarian pada Pada tabel 3 dapat terlihat bahwa responden yang memiliki sikap positif ada sebanyak 479 orang dengan presentase (69\%) masalah. Untuk Lansia yang mengikuti survey ini rata-rata memiliki keinginan tahuan dan pengetahuan mengenai COVID-19 sangat baik yaitu $(60,1 \%)$. sedangkan responden yang mempunyai sikap negatif ada sebanyak 215 orang dengan presentase $31 \%$.

Tabel 3. Sikap dalam Pencegahan COVID-19

\begin{tabular}{lll}
\hline Sikap & Jumlah & Persentase \\
\hline Positif & 479 & $69 \%$ \\
Negatif & 215 & $31 \%$ \\
& & \\
\hline
\end{tabular}

Sikap adalah tindakan seseorang terhadap suatu objek. Newcomb berpendapat sikap adalah kesanggupan untuk bergerak melaksanakan hal sudah yang ditentukan. Mengacu pada hal tersebut, maka sikap ini adalah suatu reaksi perilaku seseorang terhadap suatu rangsangan(12,25). Sikap pada pencegahan COVID-19, Lansia cukup positif dalam menyikapi hal ini, terbukti dari dari hasil survey yaitu sebesar (69\%).
Pada tabel 4 dapat terlihat bahwa sebagian besar responden melakukan praktik pencegahan COVID-19 sesuai dengan protokol kesehatan ada sebanyak 592 orang dengan presentase (85\%), sedangkan responden yang melakukan praktik pencegahan COVID-19 tidak sesuai dengan protokol kesehatan ada sebanyak 102 orang dengan presentase $(14,7$ $\%)$.

Tabel 4. Praktik dalam Pencegahan COVID-19

\begin{tabular}{lll}
\hline Praktik & Jumlah & Persentase \\
\hline Sesuai protokol Kesehatan & 592 & $85,3 \%$ \\
Tidak sesuai protokol & 102 & $14,7 \%$ \\
Kesehatan & & \\
& & \\
\hline
\end{tabular}

Praktik/perilaku, adalah merupakan reaksi seseorang terhadap suatu rangsangan yang didapatkan dari luar. Kajian Mohammadpour, menunjukkanb agaimana reaksi seseorang menghadapi rangsangan perilaku ini dapat berbentuk perhatian, perasaan, persepsi, pengetahuan dan sikap terhadap stimulus tersebut, maksudnya adalah praktik langsung yang terjadi bila kita mendapat rangsangan yang dapat diamati dengan jelas oleh orang lain. Reaksi terhadap rangsangan ini berupa tindakan atau praktik 
mudah diamati. Akan tetapi tidak semua perilaku dapat tertuang melalui sebuah tindakan, untuk merealisasikan tindakan ini membutukan hal-hal yang mendukung yaitu adanya fasilitas, sarana, dan prasarana. Pratik responden dalam hal pencegahan COVID-19 sudah sesuai dengan protokol Kesehatan $(85,3 \%)$, artinya respons stimulus menekan rasa kecemasan lansia terhadap kondisi yang terjadi mengenai COVID-19, dengan cara membangkitkan kepeduliannya terhadap perilaku pencegahan COVID-19(14,22,23).
Selanjutnya pada tabel 5 mengenai peran caregivers dalam melakukan pencegahan COVID-19 terlihat bahwa sebagian besar caregivers berperan dalam melakukan pencegahan COVID-19 terhadap lansia sudah sangat baik yaitu terdapat 614 orang (88\%), sedangkan caregivers yang kurang berperan dalam melakukan pencegahan COVID-19 ada sebanyak 80 orang (11,5\%).

Tabel 5. Peran Caregivers Dalam Melakukan Pencegahan COVID-19

\begin{tabular}{lll}
\hline Peran Caregiver & Jumlah & Persentase \\
\hline Berperan & 614 & $88,5 \%$ \\
Kurang Berperan & 80 & $11,5 \%$ \\
& & \\
\hline
\end{tabular}

Hasil penelitian Hanaoka, 2008, tentang Caregiver menemukan bahwa status perkawinan dan biaya hidup merupakan faktor yang sangat penting dalam memutuskan apakah akan memberikan pengasuh informal atau formal untuk orang tua mereka atau tidak(16). Caregivers dalam hal ini adalah seorang yang memberikan pendampingan, merawat dan mendukung lansia/pasien dalam kehidupannya seharihari $(15,20)$. Sementara itu Gardner (18) menyatakan perawatan jangka panjang pada lansia pada masa pandemi sangat signifikan terhadap tugas dan fungsi Caregivers dalam merawat lansia karena menjadi beban dalam mendukung kegiatan sehari-hari lansia seperti memandikan, memakaikan baju, menyiapkan makan, mempersiapkan obat, juga memberikan dukungan emosional, mengatur keuangan, serta membuat keputusan bagaimana memberikan perawatan selanjutnya dan berkomunikasi dengan pelayanan kesehatan formal $(16,18)$.

$$
\text { Sementara itu Caregivers pada }
$$
masyarakat di Indonesia umumnya dilakukan oleh keluarga, biasanya adalah keluarga yang terdiri dari anak, mantu, cucu atau pasangan yang tinggal bersama. Dalam suatu keluarga biasanya terdapat minimal dua orang yang saling membantu, karena mereka hidup berdampingan; mereka tentu mempunyai keterikatan batin, dan terjun dalam kegiatan sosial $(16,24)$. 
Pada tabel-tabel berikutnya adalah hasil analisis bivariate, table 6 adalah hasil analisis mengenai hubungan antara kelompok usia dengan praktik pencegahan COVID-19 didapatkan bahwa ada sebanyak (85,4\%) kelompok lansia yang melakukan praktik pencegahan COVID-19 sesuai dengan protokol kesehatan dan diperoleh pula sebanyak (85\%) kelompok usia pra-lansia yang melakukan praktik pencegahan COVID-19 sesuai dengan protokol kesehatan. Sedangkan diantara kelompok lansia ada sebanyak (14,6\%) yang melakukan praktik pencegahan COVID-19 yang tidak sesuai dengan protokol kesehatan dan diperoleh pula sebanyak (15\%) kelompok usia pra-lansia yang melakukan praktik pencegahan COVID-19 yang tidak sesuai dengan protokol kesehatan. Hasil uji statistik diperoleh nilai $\mathrm{P}=0,997$ maka dapat disimpulkan tidak ada hubungan yang signifikan antara kelompok usia dengan praktik pencegahan COVID-19.

Tabel 6. Hubungan Kelompok Usia Dengan Praktik Pencegahan COVID-19

\begin{tabular}{|c|c|c|c|c|c|c|c|}
\hline \multirow[t]{5}{*}{ Kelompok Usia } & \multicolumn{6}{|c|}{ Praktik Pencegahan } & \multirow[t]{4}{*}{ P value } \\
\hline & \multirow{3}{*}{\multicolumn{2}{|c|}{$\begin{array}{l}\text { Sesuai } \\
\text { Protokol } \\
\text { Kesehatan }\end{array}$}} & \multirow{3}{*}{\multicolumn{2}{|c|}{$\begin{array}{l}\text { Tidak Sesuai } \\
\text { Protokol }\end{array}$}} & & & \\
\hline & & & & & & & \\
\hline & & & & & & & \\
\hline & $\mathrm{N}$ & $\%$ & $\mathrm{~N}$ & $\%$ & $\mathrm{~N}$ & $\%$ & \\
\hline Lansia & 433 & 85,4 & 74 & 14,6 & 507 & 100 & 0,997 \\
\hline Pra lansia & 159 & 85 & 28 & 15 & 187 & 100 & \\
\hline
\end{tabular}

Selanjutnya pada tabel 7 dapat dilihat hasil analisis hubungan antara pendidikan dengan praktik pencegahan COVID-19 didapatkan bahwa ada sebanyak (85,6\%) responden yang memiliki pendidikan rendah tetapi melakukan praktik pencegahan COVID19 sesuai dengan protokol kesehatan dan diperoleh pula sebanyak (85\%) responden yang berpendidikan tinggi melakukan praktik pencegahan COVID-19 sesuai dengan protokol kesehatan. Sedangkan diantara responden yang berpendidikan rendah ada sebanyak
$(14,4 \%)$ melakukan praktik pencegahan COVID-19 tidak sesuai dengan protokol kesehatan dan diperoleh pula sebanyak (15\%) responden yang berpendidikan tinggi melakukan praktik pencegahan COVID-19 tidak sesuai dengan protokol kesehatan. Hasil uji statistik diperoleh nilai $\mathrm{P}=0,920$ maka dapat disimpulkan tidak ada hubungan yang signifikan antara pendidikan dengan praktik pencegahan COVID-19. 
Tabel 7. Hubungan Pendidikan Dengan Praktik Pencegahan COVID-19

\begin{tabular}{|c|c|c|c|c|c|c|c|}
\hline \multirow{3}{*}{ Pendidikan } & \multicolumn{4}{|c|}{ Praktik Pencegahan COVID-19 } & \multirow[b]{2}{*}{ Total } & & \multirow[b]{2}{*}{ P value } \\
\hline & \multicolumn{2}{|c|}{$\begin{array}{l}\text { Sesuai } \\
\text { Protokol } \\
\text { Kesehatan }\end{array}$} & \multicolumn{2}{|c|}{$\begin{array}{l}\text { Tidak Sesuai } \\
\text { Protokol }\end{array}$} & & & \\
\hline & $\mathrm{N}$ & $\%$ & $\mathrm{~N}$ & $\%$ & $\mathrm{~N}$ & $\%$ & \\
\hline Rendah & 291 & 85,6 & 49 & 14,4 & 340 & 100 & 0,920 \\
\hline Tinggi & 301 & 85 & 53 & 15 & 354 & 100 & \\
\hline
\end{tabular}

Pada tabel 8 dapat dilihat hasil analisis hubungan antara jenis kelamin dengan praktik pencegahan COVID-19 didapatkan bahwa ada sebanyak $(81,4 \%)$ lakilaki yang melakukan praktik pencegahan COVID-19 sesuai dengan protokol kesehatan dan diperoleh pula sebanyak $(86,8 \%)$ perempuan melakukan praktik pencegahan COVID-19 sesuai dengan protokol kesehatan. Sedangkan diantara laki-laki ada sebanyak
$(18,6 \%)$ yang melakukan praktik pencegahan COVID-19 tidak sesuai dengan protokol kesehatan dan diperoleh pula sebanyak $(13,2 \%)$ perempuan yang melakukan praktik pencegahan COVID-19 tidak sesuai dengan protokol kesehatan. Hasil uji statistik diperoleh nilai $\mathrm{P}=0,095$ maka dapat disimpulkan tidak ada hubungan yang signifikan antara jenis kelamin dengan praktik pencegahan COVID-19.

Tabel 8. Hubungan Jenis Kelamin Dengan Praktik Pencegahan COVID-19

\begin{tabular}{|c|c|c|c|c|c|c|c|}
\hline \multirow{3}{*}{ Jenis Kelamin } & \multicolumn{4}{|c|}{ Praktik Pencegahan COVID-19 } & \multirow[b]{2}{*}{ Total } & & \multirow{3}{*}{ P value } \\
\hline & \multicolumn{2}{|c|}{$\begin{array}{l}\text { Sesuai } \\
\text { Protokol } \\
\text { Kesehatan }\end{array}$} & \multicolumn{2}{|c|}{$\begin{array}{l}\text { Tidak Sesuai } \\
\text { Protokol }\end{array}$} & & & \\
\hline & $\mathrm{N}$ & $\%$ & $\mathrm{~N}$ & $\%$ & $\mathrm{n}$ & $\%$ & \\
\hline Laki-laki & 158 & 81,4 & 36 & 18,6 & 194 & 100 & 0,095 \\
\hline Perempuan & 434 & 86,8 & 66 & 13,2 & 500 & 100 & \\
\hline
\end{tabular}

Pada tabel 9 dapat dilihat hasil diantara responden yang memiliki analisis hubungan antara pengetahuan pengetahuan tinggi ada sebanyak $(13,9 \%)$ dengan praktik pencegahan COVID-19 melakukan praktik pencegahan COVID-19 didapatkan bahwa responden yang tidak sesuai dengan protokol kesehatan dan berpengetahuan tinggi ada sebanyak $(86,1 \%)$ melakukan praktik pencegahan COVID-19 diperoleh pula sebanyak $(15,9 \%)$ responden yang memiliki pengetahuan rendah sesuai dengan protokol kesehatan dan melakukan praktik pencegahan COVID-19 diperoleh pula sebanyak (84,1\%) responden tidak sesuai dengan protokol kesehatan. Hasil yang berpengetahuan rendah tetapi tetap uji statistik diperoleh nilai $\mathrm{P}=0,542$ maka melakukan praktik pencegahan COVID-19 dapat disimpulkan tidak ada hubungan yang sesuai dengan protokol kesehatan. Sedangkan 
Tabel 9. Hubungan Pengetahuan Dengan Praktik Pencegahan COVID-19

\begin{tabular}{|c|c|c|c|c|c|c|c|}
\hline \multirow{3}{*}{ Pengetahuan } & \multicolumn{4}{|c|}{ Praktik Pencegahan COVID-19 } & & & \multirow[b]{2}{*}{ P value } \\
\hline & \multicolumn{2}{|c|}{$\begin{array}{l}\text { Sesuai } \\
\text { Protokol } \\
\text { Kesehatan }\end{array}$} & \multicolumn{2}{|c|}{$\begin{array}{l}\text { Tidak Sesuai } \\
\text { Protokol }\end{array}$} & Total & & \\
\hline & $\mathrm{N}$ & $\%$ & $\mathrm{n}$ & $\%$ & $\mathrm{n}$ & $\%$ & \\
\hline Tinggi & 359 & 86,1 & 58 & 13,9 & 417 & 100 & \\
\hline Rendah & 233 & 84,1 & 44 & 15,9 & 277 & 100 & 0,542 \\
\hline
\end{tabular}

Pada tabel 10 dapat dilihat hasil analisis hubungan antara kelompok sikap dengan praktik pencegahan COVID-19 didapatkan bahwa ada sebanyak $88,1 \%$ responden yang mempunyai sikap positif melakukan praktik pencegahan COVID-19 sesuai dengan protokol kesehatan dan diperoleh pula sebanyak $79,1 \%$ responden yang memiliki sikap negatif tetapi melakukan praktik pencegahan COVID-19 sesuai dengan protokol kesehatan. Sedangkan diantara kelompok responden yang mempunyai sikap positif ada sebanyak $11,9 \%$ melakukan praktik pencegahan COVID-19 tidak sesuai dengan protokol kesehatan dan diperoleh pula sebanyak 20,9 \% responden yang memiliki sikap negatif melakukan praktik pencegahan COVID-19 tidak sesuai dengan protokol kesehatan. Hasil uji statistik diperoleh nilai $\mathrm{P}=0,003$ maka dapat disimpulkan ada hubungan yang signifikan antara sikap dengan praktik pencegahan COVID-19. Dari hasil analisis diperoleh pula nilai $O R=1,960$ artinya responden yang mempunyai sikap positif mempunyai peluang 1,960 kali melakukan praktik pencegahan COVID-19 dibandingkan dengan responden yang memiliki sikap negatif.

Table 10. Hubungan Sikap Dengan Praktik Pencegahan COVID-19

\begin{tabular}{|c|c|c|c|c|c|c|c|c|}
\hline \multirow{6}{*}{ Sikap } & \multicolumn{4}{|c|}{ Praktik Pencegahan COVID- } & \multirow{5}{*}{ Total } & & \multirow{6}{*}{$\begin{array}{l}\mathrm{P} \\
\text { value }\end{array}$} & \multirow{6}{*}{$\begin{array}{l}\text { OR } \\
95 \% \mathrm{Cl}\end{array}$} \\
\hline & \multicolumn{4}{|c|}{19} & & & & \\
\hline & \multirow{3}{*}{\multicolumn{2}{|c|}{$\begin{array}{l}\text { Sesuai } \\
\text { Protokol } \\
\text { Kesehatan }\end{array}$}} & \multirow{3}{*}{\multicolumn{2}{|c|}{$\begin{array}{l}\text { Tidak Sesuai } \\
\text { Protokol }\end{array}$}} & & & & \\
\hline & & & & & & & & \\
\hline & & & & & & & & \\
\hline & $\mathrm{N}$ & $\%$ & $\mathrm{~N}$ & $\%$ & $\mathrm{~N}$ & $\%$ & & \\
\hline Positif & 422 & 88,1 & 57 & 11,9 & 479 & 100 & & \\
\hline & & 701 & & 200 & & 100 & 0,003 & 1,960 \\
\hline Negatıt & $1 / 0$ & 19,1 & 45 & 20,9 & 215 & 100 & & $(1,275-3,011)$ \\
\hline
\end{tabular}

Pada tabel 11 dapat dilihat hasil analisis hubungan peran caregivers dalam pencegahan COVID-19 dengan praktik pencegahan COVID-19 didapatkan bahwa ada sebanyak $86 \%$ caregiver berperan dalam melakukan praktik pencegahan COVID-19 sesuai dengan protokol kesehatan dan diperoleh pula sebanyak (64\%) caregivers 
yang kurang berperan dalam pencegahan COVID-19 tetapi tetap melakukan praktik pencegahan COVID-19 sesuai dengan protokol kesehatan. Sedangkan diantara caregiver yang berperan dalam pencegahan COVID-19 ada sebanyak (14\%) yang melakukan praktik pencegahan COVID-19 tidak sesuai dengan protokol kesehatan dan diperoleh pula sebanyak 20\% caregivers yang kurang berperan dalam pencegahan COVID-19 dan melakukan praktik pencegahan COVID-19 tidak sesuai dengan protokol kesehatan. Hasil uji statistik diperoleh nilai $\mathrm{P}=0,209$ maka dapat disimpulkan tidak ada hubungan yang signifikan antara peran caregiver dengan praktik pencegahan COVID-19.

Tabel 11. Hubungan Peran Caregivers dalam Pencegahan COVID-19 dengan Praktik Pencegahan COVID-19

\begin{tabular}{|c|c|c|c|c|c|c|c|}
\hline \multirow{3}{*}{ Peran Caregivers } & \multicolumn{4}{|c|}{ Praktik Pencegahan COVID-19 } & \multirow{2}{*}{\multicolumn{2}{|c|}{ Total }} & \multirow{3}{*}{ P value } \\
\hline & \multicolumn{2}{|c|}{$\begin{array}{l}\text { Sesuai } \\
\text { Protokol } \\
\text { Kesehatan }\end{array}$} & \multicolumn{2}{|c|}{$\begin{array}{l}\text { Tidak Sesuai } \\
\text { Protokol }\end{array}$} & & & \\
\hline & $\mathrm{n}$ & $\%$ & $\mathrm{n}$ & $\%$ & $\mathrm{n}$ & $\%$ & \\
\hline Berperan & 528 & 86 & 86 & 14 & 614 & 100 & 0,209 \\
\hline Kurang Berperan & 64 & 80 & 16 & 20 & 80 & 100 & \\
\hline
\end{tabular}

\section{KESIMPULAN}

Kesimpulan dari penelitian ini menunjukkan bahwa, pengetahuan lansia dan care givers tentang COVID-19 cukup tinggi, sikapnya sebagian besar positif dan praktiknya sebagian besar telah sesuai dengan protokol kesehatan. Peran caregiver nonformal dalam keluarga dirasakan telah cukup baik. Perlakuan salah yang diterima oleh lansia dari anggota keluarga ternyata presentasinya sangat kecil, berarti lansia masih mendapatkan penghormatan dari anggota keluarganya. Tidak ada hubungan yang signifikan antara usia, pendidikan, pengetahuan, sikap dan praktik dengan perilaku pencegahan COVID-19.

Selain itu, dari hasil penelitian juga diketahui bahwa lansia perempuan masih menempati porsi tertinggi dalam partisipasi pada pencegahan COVID-19, oleh karena itu Pemerintah sebaiknya mendorong kesetaraan gender dengan memperkenalkan kebijakan sensitif gender untuk memberikan perhatian dan dukungan kepada wanita yang merupakan pengasuh non-formal dalam keluarga. Selain itu juga perlu dilakukan upaya untuk menerapkan kampanye pendidikan, guna meningkatkan proporsi pengetahuan tentang COVID-19, agar penyebaran virus dapat dihentikan.

\section{DAFTAR PUSTAKA}

1. World Health Organization (WHO)1.2020.https://www.who.int/healt h-topics/coronavirus. Diakses 18 Januari 2020. 
2. Kementerian Kesehatan Republik Indonesia.2017. Pedoman Kesiapsiagaan Menghadapi MERSCoV di Indonesia.

3. CDC. (2020, April 19). Symptoms of Coronavirus 2020. Retrieved from https://www.cdc.gov/coronavirus/2019ncov/symptomstesting/symptoms.html.

4. Sarafino E.P., 2006. Health psychology. Amerika Serikat: John Wiley \& sons Inc.

5. WHO. (2013). World health statistics 2013. Geneva: WHO press.

6. Depkes RI. Pedoman Perawatan Kesehatan Usia Lanjut di Rumah. Jakarta: Departemen Kesehatan RI. 2006.

7. World Health Organization (WHO)2.2020.Global surveillance for human infection with novelcoronavirus(2019-

ncov).https://www.who.int/publicationsdetail/global-surveillance-for-humaninfection-with-novel-coronavirus-(2019ncov). Diakses20Januari2020.

8. Allender \& Spradley. 2005. Community Health Nursing: Concept and Practice. (5th ed). Philadelhia: Lippincott.

9. Kung, B. W. (2003). Chinese American caregiver of patient with schizophrenia, Family Challenges. New York : Guildford.

10. Bloom, Benjamin S., etc. 1956. Taxonomy of Educational Objectives : The Classification of Educational Goals, Handbook I Cognitive Domain. New York : Longmans, Green and Co.
11. Azwar S. 2013. Sikap Manusia: Teori dan Pengukurannya. Yogyakarta: Pustaka.

12. Newcomb, Theodore M. et.al. 1978, Psikologi Sosial, Bandung: CV. Diponegoro.

13. Skinner, B. F. 1996. Science and Human Behaviour. New York: McMillan.

14. Notoatmodjo, S. 2007. Promosi Kesehatan dan IImu Perilaku. Jakarta : Rineka. Cipta.

15. Awad, G., \& Voruganti, L.N.P. (2008). The Burden of Schizophrenia on Caregiver. Review Article

16. Hanaoka, C., \& Norton, E. C. (2008). Informal and formal care for elderly persons: How adult children's characteristics affect the use of formal care in Japan. Social Science and Medicine, 67(6), 1002-1008. https://doi.org/10.1016/j.socscimed.200 8.05 .006

17. Irving, J., Davis, S., \& Collier, A. (2017). Aging With Purpose: Systematic Search and Review of Literature Pertaining to Older Adults and Purpose. International Journal of Aging and Human Development, 85(4), 403-437. https://doi.org/10.1177/0091415017702 $\underline{908}$

18. Gardner, W., States, D., \& Bagley, N. (2020). The Coronavirus and the Risks to the Elderly in Long-Term Care. Journal of Aging and Social Policy, 32(4-5), 310315. 
https://doi.org/10.1080/08959420.2020. $\underline{1750543}$

19. Geldsetzer, P. (2020). Using rapid online surveys to assess perceptions during infectious disease outbreaks: a crosssectional survey on Covid-19 among the general public in the United States and United Kingdom. MedRxiv: The Preprint Server for Health Sciences. https://doi.org/10.1101/2020.03.13.2003 $\underline{5568}$

20. Graham Carlos, W., Dela Cruz, C. S., Cao, B., Pasnick, S., \& Jamil, S. (2020). Novel Wuhan (2019-NCoV) coronavirus. American Journal of Respiratory and Critical Care Medicine, 201(4), P7-P8. https://doi.org/10.1164/rccm.2014P7

21. Feng, S., Shen, C., Xia, N., Song, W., Fan, M., \& Cowling, B. J. (2020). Rational use of face masks in the COVID-19 pandemic. The Lancet Respiratory Medicine, 8(5), 434-436. https://doi.org/10.1016/S22132600(20)30134-X

22. Mohammadpour, A., Sadeghmoghadam, L., Shareinia, H., Jahani, S., \& Amiri, F. (2018). Investigating the role of perception of aging and associated factors in death anxiety among the elderly. Clinical Interventions in Aging, 13, 405-410. https://doi.org/10.2147/CIA.S150697
23. Padala, P. R., Jendro, A. M., Gauss, C. H., Orr, L. C., Dean, K. T., Wilson, K. B., Parkes, C. M., \& Padala, K. P. (2020). Participant and Caregiver Perspectives on Clinical Research During Covid-19 Pandemic. Journal of the American Geriatrics Society, 68(6), E14-E18. https://doi.org/10.1111/igs.16500

24. Ratnasari, N. Y., Marni, M., \& Husna, P. H. (2019). Knowledge, Behavior, and Role of Health Cadres in The Early Detection of New Tuberculosis Case in Wonogiri. Jurnal Kesehatan Masyarakat. https://doi.org/10.15294/kemas.v15i2.2064 7

25. Zhong, B. L., Luo, W., Li, H. M., Zhang, Q. Q., Liu, X. G., Li, W. T., \& Li, Y. (2020). Knowledge, attitudes, and practices towards COVID-19 among chinese residents during the rapid rise period of the COVID-19 outbreak: A quick online cross-sectional survey. International Journal of Biological Sciences, 16(10), 1745-1752. https://doi.org/10.7150/ijbs.45221 